\title{
Aspects of a steel-framed building's life cycle that influence its environmental sustainability
}

\author{
D. N. Kaziolas \\ Eastern Macedonia and Thrace Institute of Technology, Kavala, Greece
}

I. Zygomalas

Department of Civil Engineering, Aristotle University of Thessaloniki, Thessaloniki, Greece

G. E. Stavroulakis

Department of Production Engineering and Management, Technical University of Crete, Chania, Greece

C. C. Baniotopoulos

Department of Civil Engineering, Aristotle University of Thessaloniki, Greece and Chair of Sustainable Energy Systems, School of Civil Engineering, The University of Birmingham, Birmingham, United Kingdom

\begin{abstract}
The assessment of the environmental impact caused throughout the life cycle of a structure is a major step towards optimizing its sustainability. Based on methodologies such as life cycle assessment, these calculations can be used to determine the life cycle stages -as well as the very processes or materialsthat are responsible for the largest environmental impacts. It is then in the hands of those carrying out the construction works to incorporate this knowledge into standard project delivery with the aim to minimize environmental impacts and ultimately increase the sustainability of the construction sector. This research aims to materialize this prospect by investigating the environmental impact caused by the life cycle of a steel-framed building in order to determine the aspects that significantly influence its sustainability. An existing building is selected as the basis of the calculations and the influence of several factors is assessed through the results that are obtained. The conclusions drawn highlight the issues that affect the environmental sustainability of steel construction, while also furthering knowledge concerning the determination of factors and criteria that can be used as the basis for recommendations that can be applied to similar projects is produced.
\end{abstract}

\section{INTRODUCTION}

The movement for sustainable development was developed as a top priority policy among several of the world's governments and after only several years it has come to be introduced into almost every aspect of current business activities. Out of the three dimensions of sustainability that have been identified -economic, social and environmental- it is the environmental issues that are currently being prioritized as more urgent in regard to the immediate future of mankind. The need for more sustainable solutions is globally acknowledged. As a result, terms such as "reduced carbon footprint" and "green" products or services are constantly being used to advertise the achievements of product manufacturers and service providers that have managed to respond to the sustainability challenge and adjust their businesses to these new requirements.

The construction sector has been identified as one of the largest consumers of raw materials and energy and is therefore actively involved in establishing practices that promote sustainability in regard to both construction materials and processes (Bragança et al., 2007 and Intini and Kühtz, 2011). Most construction product manufacturers are engaged in re- search aimed at lowering their products' environmental impact in order to gain a competitive advantage in today's sustainability-oriented market (Haapio, 2010). Construction companies are on a similar track; the environmental impact of construction processes required for the delivery of technical projects are being analyzed and assessed in order to identify the areas where improvements can be made.

Especially in sectors such as steel construction, where the sustainability potential of the main materials used is increased to begin with (Burgan and Sansom, 2006), the optimization of construction processes becomes a crucial issue in relation to achieving sustainability (Kaziolas et al., 2013). The current research investigates the influence of a number of aspects related to the delivery of steel structure projects on the environmental impact caused by the life cycle of the project. An existing steel-framed building is selected as the basis of the calculations and the influence of the examined aspects is assessed through the results obtained. The selection of the construction aspects to be examined is based on research regarding the environmental impact of steel structures and particularly buildings. Each aspect is examined individually -with all other parameters 
kept constant- in order to isolate its effects and quantify their environmental impact.

\section{METHODOLOGY}

The delivery of any construction project includes a series of construction processes that are performed and certain amounts of construction materials that are used. In order to include as many of these processes and materials as possible -and thus create an accurate environmental account of the project's delivery- the concept of the life cycle is used. The life cycle of construction projects consists of four main stages, namely raw material acquisition, construction, use/maintenance and waste treatment.

The methodology which allows the quantification of the environmental impact caused by the life cycle of a project is life cycle assessment (LCA) (ISO, 20006a and 2006b, Zygomalas et al., 2013).

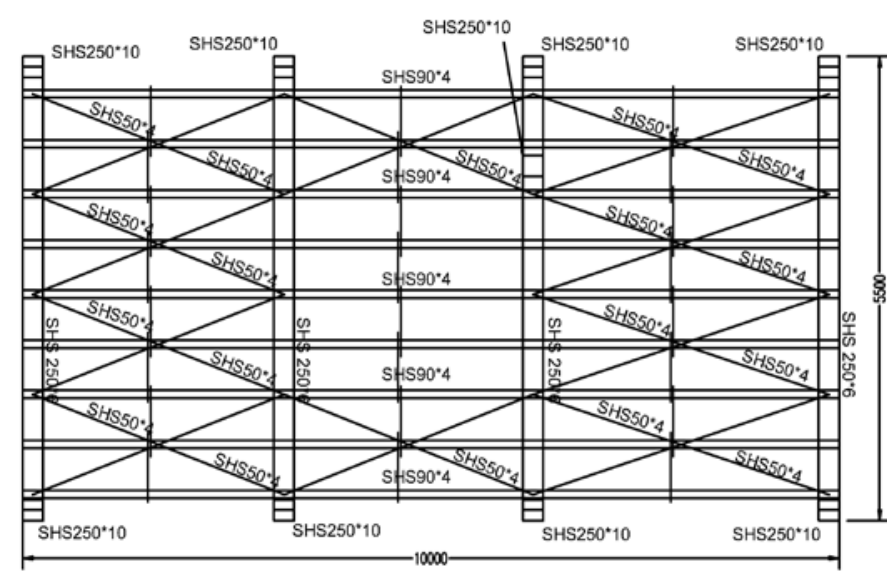

Figure 1. Plan view of the single-storey steel-framed building.

The existing steel-framed building which is selected as the basis for the calculations required is a single-storey $5.5 \times 10 \mathrm{~m}$ plan view building (Figure 1) with a steel deck, constructed in Thessaloniki, Greece. The load-bearing frame of the building is constructed of SHS (square hollow sections) structural steel sections. The main construction materials and processes that are used for the building and are taken into account for the current analyses are briefly described in Table 1.

The aspects of the building's life cycle that are examined are presented in Table 2. The environmental impact assessment methodology used for the LCA analyses presented is the Eco-Indicator 99 methodology (Eco-indicator 99 (E) V2.08 / Europe EI $99 \mathrm{E} / \mathrm{E})$. The environmental impact results according to this methodology are calculated in EcoIndicator points $(\mathrm{Pt})$, where $1 \mathrm{Pt}$ is representative of one thousandth of the yearly environmental load of one average European inhabitant (The Netherlands Ministry of Housing, Spatial Planning and the Environment, 2000). The environmental data used are mainly drawn from existing LCI (life cycle inventory) databases such as the LCI database developed at the Aristotle University of Thessaloniki (Zygomalas et al., 2012) and the Ecoinvent LCI database.

Table 1. Main construction materials and processes for the steel-framed building

\begin{tabular}{|c|c|}
\hline $\begin{array}{c}\text { Main materials and } \\
\text { processes }\end{array}$ & Description \\
\hline Structural steel sections & $\begin{array}{l}\text { Includes the structural steel } \\
\text { sections used for the construc- } \\
\text { tion of the load-bearing frame } \\
\text { and the support of the steel } \\
\text { deck and roof }\end{array}$ \\
\hline $\begin{array}{l}\text { Connection and joints of } \\
\text { steel elements }\end{array}$ & $\begin{array}{l}\text { Refers to the connection ele- } \\
\text { ments used for the structural } \\
\text { steel elements, including bolts, } \\
\text { welding, steel plates, steel } \\
\text { bars and connectors }\end{array}$ \\
\hline Concrete & $\begin{array}{l}\text { Includes the quantities of con- } \\
\text { crete required for the build- } \\
\text { ing's foundation and slabs }\end{array}$ \\
\hline $\begin{array}{l}\text { Steel reinforcement for } \\
\text { concrete }\end{array}$ & $\begin{array}{l}\text { Refers to the steel reinforce- } \\
\text { ment bars for the reinforce- } \\
\text { ment of the concrete }\end{array}$ \\
\hline Excavation & $\begin{array}{l}\text { Refers to the excavation re- } \\
\text { quired for the construction of } \\
\text { the building }\end{array}$ \\
\hline $\begin{array}{l}\text { Steel sheet profile for } \\
\text { deck }\end{array}$ & $\begin{array}{l}\text { Refers to the steel profile used } \\
\text { for the construction of the } \\
\text { steel deck }\end{array}$ \\
\hline
\end{tabular}

Table 2. Aspects of the steel building's life cycle that are examined

\begin{tabular}{|c|c|}
\hline Life cycle aspect & Description \\
\hline $\begin{array}{l}\text { Steel materials acquisi- } \\
\text { tion }\end{array}$ & $\begin{array}{l}\text { Refers to the whether the con- } \\
\text { struction materials have been } \\
\text { manufactured locally or from } \\
\text { imported semi-finished steel } \\
\text { products from foreign suppli- } \\
\text { ers }\end{array}$ \\
\hline $\begin{array}{l}\text { Material transport dis- } \\
\text { tance to site }\end{array}$ & $\begin{array}{l}\text { Refers to the distance assumed } \\
\text { for the transport of the con- } \\
\text { struction materials from the } \\
\text { suppliers to the site }\end{array}$ \\
\hline $\begin{array}{l}\text { Retrieved materials } \\
\text { transport distance }\end{array}$ & $\begin{array}{l}\text { Refers to the distance assumed } \\
\text { for the transport of the con- } \\
\text { struction materials that are re- } \\
\text { trieved at the end of the build- } \\
\text { ing service life and after the } \\
\text { decision for demolition has } \\
\text { been made }\end{array}$ \\
\hline Steel recycling rate & $\begin{array}{l}\text { Refers to the percentage of re- } \\
\text { trieved steel materials that are } \\
\text { recycled at the end of the } \\
\text { building's service life }\end{array}$ \\
\hline
\end{tabular}

\section{ENVIRONMENTAL IMPACT RESULTS}

\subsection{Steel materials acquisition}

The acquisition of the structural steel materials used for the construction of the examined building can either be manufactured locally in Greece (local 
steel products) or processed into final products from semi-finished steel products which have been imported from foreign suppliers (semi-imported steel products). Each acquisition route has its characteristics, and the purpose of the current analysis is to determine their effect on the building's life cycle environmental impact. Two scenarios are defined -one for each acquisition route- and the respective environmental impacts are calculated.

The distance for the transport of the construction materials from the suppliers to the site is assumed to be $20 \mathrm{~km}$, while the distance for their transport to the various waste treatment facilities (recycling plants, landfills, etc.) is assumed to be $50 \mathrm{~km}$. In regard to the waste treatment of the retrieved construction materials at the end of the building's life cycle, it is assumed that $90 \%$ of the steel products is retrieved and sent for recycling, while the remaining $10 \%$ is considered irretrievable and is therefore disposed of in landfills. For the concrete, it is assumed that $80 \%$ is retrieved and sent for recycling (crushed to be used as gravel), while the remaining $20 \%$ is considered irretrievable and disposed of in landfills.

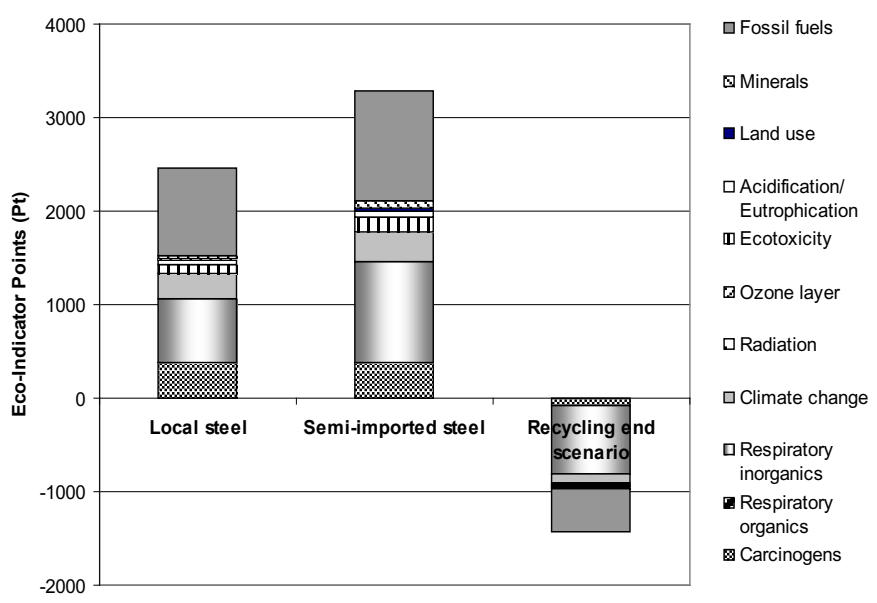

Figure 2. Environmental impact of the building's construction for each acquisition route and the recycling end scenario.

Based on these assumptions, the environmental impact of the building's life cycle is calculated. The results are presented in Figure 2 for the construction of the building with each of the two acquisition routes (local and semi-imported steel products) and the recycling end scenario, which is the same for the two acquisition scenarios. As can be observed, the construction of the steel building with locally manufactured steel products causes a smaller environmental impact $(2457 \mathrm{Pt})$ in comparison to the semiimported steel product construction scenario (3282 $\mathrm{Pt})$. The recycling scenario provides significant environmental benefits $(-1431 \mathrm{Pt}$, the negative value referring to benefit rather than burden), which are however differently utilized by each of the two acquisition route construction scenarios. In specific, the total environmental impact of the building's life cycle (the result of adding the impact of the construction and the benefit of recycling) with the local steel products is calculated at $1026 \mathrm{Pt}$, while for the semi-imported products the total life cycle impact is $1852 \mathrm{Pt}$. It is therefore evident that the acquisition route of the structural steel materials can almost double the total environmental impact of a steel building's life cycle.

\subsection{Materials transport distance to site}

The construction materials required for the construction of the steel building have to be transported to the site from the various suppliers. These transport processes often cause noticeable environmental impact and should therefore be included in construction-related LCA analyses. The amount of environmental impact caused by transport processes depends on the weight of the materials transported and the distance that has to be covered. The means of transport is also important, but for the current analyses, it is assumed that all materials are transported by trucks. In order to examine the influence of the transport distance from the suppliers to the construction site, three scenarios are defined. For the first scenario a $10 \mathrm{~km}$ distance is assumed, referring to suppliers that are in close proximity to the site. For the second scenario, the same distance is assumed at $30 \mathrm{~km}$, referring to cases where the suppliers are further away from the site. Thirdly, an $80 \mathrm{~km}$ distance is examined, referring to suppliers that are quite far from the project's site.

In regard to the remaining parameters, the distance for the transport of the retrieved materials to the various waste treatment facilities is assumed to be $50 \mathrm{~km}$, while the steel materials are assumed to be manufactured locally. In regard to the waste treatments, it is assumed that $90 \%$ of steel products is recycled and the remaining $10 \%$ is disposed of in landfills, while $80 \%$ of the concrete is recycled and $20 \%$ is disposed of in landfills.

Based on these assumptions, the environmental impact of the building's life cycle is calculated. The results are presented in Figure 3 for the construction of the building with each of the three transport distances assumed (10,30 and $80 \mathrm{~km}$ to the site) and the recycling end scenario, which is the same for the three distance scenarios. As can be observed, the construction of the steel building with the $10 \mathrm{~km}$ distance to the site causes a slightly smaller environmental impact $(2430 \mathrm{Pt})$ in comparison to the $30 \mathrm{~km}$ $(2484 \mathrm{Pt})$ and the $80 \mathrm{~km}$ scenario $(2617 \mathrm{Pt})$. The recycling scenario again provides environmental benefits of $-1431 \mathrm{Pt}$ (the negative value referring to benefit rather than burden). The total environmental impact of the building's life cycle (the result of adding the impact of the construction and the benefit of recycling) is found at $1000 \mathrm{Pt}$ for the $10 \mathrm{~km}$ scenar- 
io, $1053 \mathrm{Pt}$ for the $30 \mathrm{~km}$ (a 5,3\% increase) and 1186 $\mathrm{Pt}$ for the $80 \mathrm{~km}$ scenario (an 18,6\% increase from the $10 \mathrm{~km}$ scenario). It is therefore evident that the transport distance of the construction materials from the suppliers to the site have a relatively limited effect on the total environmental impact of the building, which can however increase noticeably for proportionally increased transport distances.
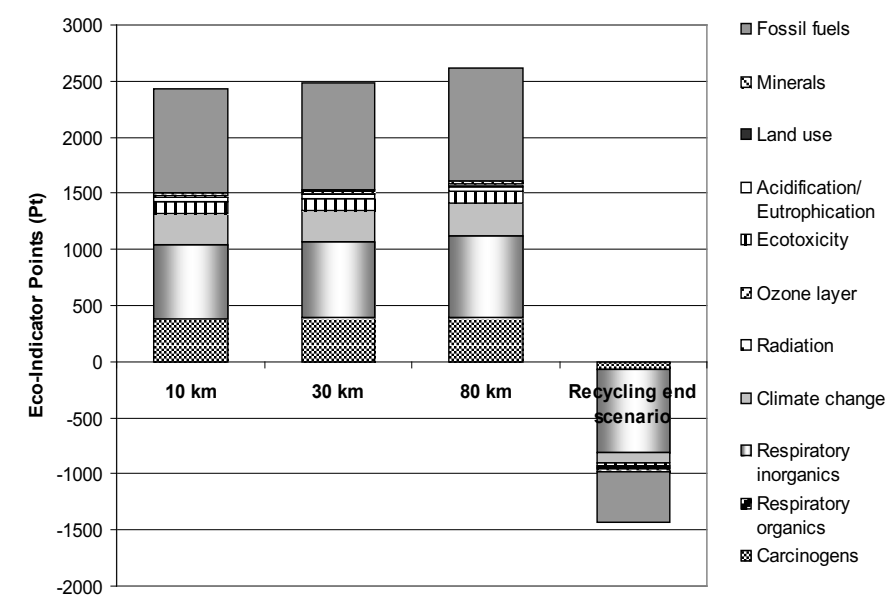

Figure 3. Environmental impact of the building's construction for the three transport distances to the site scenarios and the recycling end scenario.

\subsection{Retrieved materials transport distance}

At the end of a building's service life and after the decision for demolition has been made, efforts are made to retrieve as much of the construction materials used. This is done in order for the retrieved materials to be sent for recycling or reuse and avoid disposing them in landfills, which causes further environmental impact. After the demolition has been completed, the retrieved materials have to be transported to various waste treatment facilities, such as sorting or recycling plants. These facilities are often found in quite larger distances from a building's site compared to material suppliers, as they are less in number and operate only in specific locations. As a result, the processes required for the transport of the retrieved materials to these facilities often cause noticeable environmental impact and should therefore be included in construction-related LCA analyses.

As was the case with the transport of the materials to the construction site, the amount of environmental impact caused depends on the weight of the materials transported and the distance that has to be covered. It is again assumed that all materials are transported by trucks and in order to examine the influence of the transport distance to the waste treatment facilities, three scenarios are defined. For the first scenario a $50 \mathrm{~km}$ distance is assumed, for the second a $100 \mathrm{~km}$ distance and thirdly, a $200 \mathrm{~km}$ dis- tance is examined. In regard to the remaining parameters, the distance for the transport of the construction materials to the site is assumed to be 20 $\mathrm{km}$, while the steel materials are assumed to be manufactured locally. In regard to the waste treatments, it is again assumed that $90 \%$ of steel products is recycled and the remaining $10 \%$ is disposed of in landfills, while $80 \%$ of the concrete is recycled and $20 \%$ is disposed of in landfills.

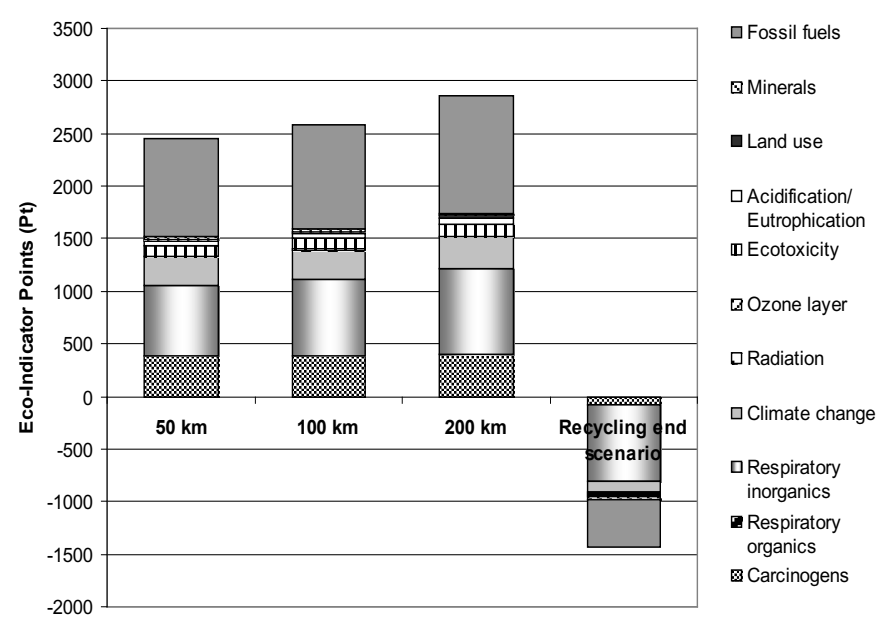

Figure 4. Environmental impact of the building's construction for the three transport distance to the waste treatment facilities scenarios and the recycling end scenario.

The environmental impact results are presented in Figure 4 the building's construction for the three transport distance to the waste treatment facilities scenarios (50,100 and $200 \mathrm{~km}$ to the site) and the recycling end scenario, which is the same for the three scenarios. As can be observed, the construction of the steel building with the $50 \mathrm{~km}$ distance to the waste treatment facilities causes a slightly smaller environmental impact $(2457 \mathrm{Pt})$ in comparison to the $100 \mathrm{~km}(2590 \mathrm{Pt})$ and the $200 \mathrm{~km}$ scenario $(2857$ $\mathrm{Pt})$. The recycling scenario again provides environmental benefits of $-1431 \mathrm{Pt}$ (the negative value referring to benefit rather than burden).

The total environmental impact of the building's life cycle (the result of adding the impact of the construction and the benefit of recycling) is found at $1026 \mathrm{Pt}$ for the $50 \mathrm{~km}$ scenario, $1160 \mathrm{Pt}$ for the 100 $\mathrm{km}$ (a 13\% increase) and $1426 \mathrm{Pt}$ for the $200 \mathrm{~km}$ scenario (a $39 \%$ increase from the $50 \mathrm{~km}$ scenario). It is therefore evident that the transport distance of the retrieved construction materials to the waste treatment facilities has a significant effect on the total environmental impact of the building, which, as expected, increases for proportionally increased transport distances. 


\subsection{Steel recycling rate}

Steel is a material with perhaps one of the highest recycling potential among construction materials. The capacity of the material to be melted and used for the manufacturing of new quantities of steel without the need of newly extracted raw materials and without any loss in quality and properties provides the basis for the material's increased sustainability within construction. It is, however, up to the designers and construction professionals involved in a technical project to materialize this potential by applying measures to enable the retrieval of as large percentages of stele materials as possible during the demolition stage. The recycling rate of the steel materials retrieved therefore plays an important role in determining the total environmental impact of a project's life cycle. For the current research, three recycling scenarios are defined, as displayed in Table 3. It is noted that the recycling rate of all the other construction materials is kept constant as the purpose of the analyses is to depict the sustainability potential of steel as a construction material.

In regard to the remaining parameters, the distance for the transport of the construction materials to the site is assumed to be $20 \mathrm{~km}$, the distance for their transport to the waste treatment facilities is assumed to be $50 \mathrm{~km}$ and the steel materials are assumed to be manufactured locally.

Table 3. End-of-life scenarios developed for the steel materials recycling rate

\begin{tabular}{|c|c|}
\hline End scenario & Waste treatment \\
\hline $90 \%$ recycling rate & $\begin{array}{l}90 \% \text { of structural and reinforcing } \\
\text { steel recycled } \\
10 \% \text { considered irretrievable and } \\
\text { disposed in landfill } \\
80 \% \text { of the concrete recycled } \\
\text { (crushed to be used as gravel) } \\
20 \% \text { considered irretrievable and } \\
\text { disposed in landfill }\end{array}$ \\
\hline $50 \%$ recycling rate & $\begin{array}{l}50 \% \text { of structural and reinforcing } \\
\text { steel recycled } \\
50 \% \text { considered irretrievable and } \\
\text { disposed in landfill } \\
80 \% \text { of the concrete recycled } \\
\text { (crushed to be used as gravel) } \\
20 \% \text { considered irretrievable and } \\
\text { disposed in landfill }\end{array}$ \\
\hline $30 \%$ recycling rate & $\begin{array}{l}30 \% \text { of structural and reinforcing } \\
\text { steel recycled } \\
70 \% \text { considered irretrievable and } \\
\text { disposed in landfill } \\
80 \% \text { of the concrete recycled } \\
\text { (crushed to be used as gravel) } \\
20 \% \text { considered irretrievable and } \\
\text { disposed in landfill }\end{array}$ \\
\hline
\end{tabular}

Based on these assumptions, the environmental impact of the building's life cycle is calculated. The results are presented in Figure 5 for the construction of the building and the three steel recycling rate sce- narios. As can be observed, each recycling scenario provides environmental benefits starting from -482 $\mathrm{Pt}$ (the negative value referring to benefits) for the $30 \%$ rate, increasing to $-798 \mathrm{Pt}$ for the $50 \%$ steel recycling scenario and reaching $-1431 \mathrm{Pt}$ for the $90 \%$ recycling rate. The total environmental impact of the building's life cycle (the result of adding the impact of the construction and the benefit of recycling) for the $30 \%$ scenario is $1975 \mathrm{Pt}, 1659 \mathrm{Pt}$ for the $50 \%$ recycling scenario (16\% decrease) and $1026 \mathrm{Pt}$ for the $90 \%$ scenario (48\% decrease compared to the $30 \%$ scenario). It is therefore evident that the recycling rate of the steel materials in construction projects significantly affects the total environmental impact of the project's life cycle as it can reduce it to almost half of what it would be in case steel recycling was only partly utilized.

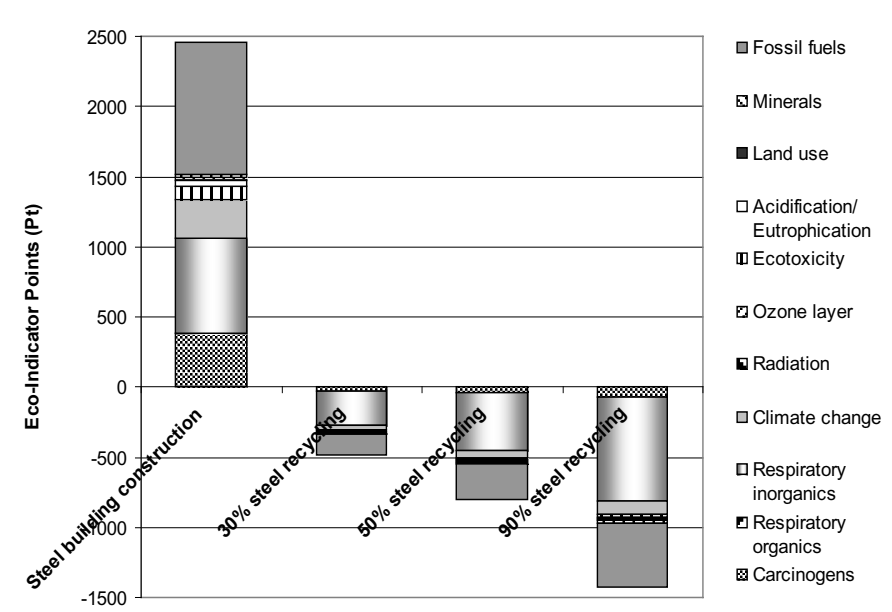

Figure 5. Environmental impact of the building's construction and the three recycling scenarios.

\section{CONCLUSIONS}

The application of methodologies such as life cycle assessment (LCA) within construction has allowed the quantification of the environmental impact caused throughout the life cycle of technical projects such as buildings. The current research investigated the influence of several key aspects of a steel building project's life cycle on the total environmental impact caused. An existing steel-framed building was used as the basis for the calculations and a series of LCA analyses were conducted. The findings can be used for the formation of guidelines regarding steel construction projects in terms of environmental impact optimization.

The first aspect of steel construction which was examined was the acquisition route of the structural steel products used. It was found that the construction of the building with locally manufactured structural steel causes a smaller environmental impact in comparison to products that have been processed 
from semi-finished steel products which have been imported from foreign suppliers. Further examination of the total environmental impact of the building's life cycle (the result of adding the impact of the construction and the benefit of recycling) showed that the acquisition route of the structural steel materials can almost double the total environmental impact of a steel building's life cycle.

The transport of the construction materials was also found to noticeably influence the total life cycle environmental impact. Although the transport distance of the construction materials from the suppliers to the site was found to have a relatively limited effect, the transport of the retrieved construction materials to the waste treatment facilities significantly influences the total environmental impact of the building. As expected, the influence of both transport processes increases noticeably for proportionally increased distances.

The recycling rate of the steel materials retrieved at the building's demolition stage was also investigated and was found to significantly affect the total environmental impact of the project's life cycle. In specific, a $90 \%$ steel recycling rate was shown to reduce the total environmental impact to almost half of what it would be in case only $30 \%$ of the steel was recycled.

\section{ACKNOWLEDGMENTS}

This research has been co-financed by the European Union (European Social Fund - ESF) and Greek national funds through the Operational Program "Education and Lifelong Learning" of the National Strategic Reference Framework (NSRF) - Research Funding Program: ARCHIMEDES III. Investing in knowledge society through the European Social Fund.

\section{REFERENCES}

Bragança, L., Mateus, R. and Koukkari H. 2007. "Perspectives of building sustainability assessment". In: Bragança, L., Pinheiro, M.D., Jalali, S., Mateus, R., Amoêda, R. and Guedes, M.C. (editors). Portugal SB07 - Sustainable construction, materials and practices, IOS Press, The Netherlands, pp 356-365.

Burgan, B.A. and Sansom, M.R., 2006. Sustainable steel construction. Journal of Constructional Steel Research, 62 (2006), 1178-1183.

Haapio A. 2010. The Role of Environmental Assessment of Buildings. Proceedings of the International Symposium "Sustainable Construction - A Life Cycle Approach in Engineering" of the COST Action C25 Sustainability of Constructions Integrated Approach to Life-time Structural Engineering, Malta, 23-25 July 2010, pp. 17-24.

Intini, F. and Kühtz, S. 2011. Recycling in buildings: an LCA case study of a thermal insulation panel made of polyester fiber, recycled from post-consumer PET bottles. The International Journal of Life Cycle Assessment, SpringerVerlag, Volume 16, Issue 4, pp 306-315.
ISO, International Organization for Standardization 2006a. International Standard ISO 14040:2006 Environmental management - Life cycle assessment - Principles and framework, International Organization for Standardization.

ISO, International Organization for Standardization 2006b. International Standard ISO 14044:2006 Environmental management - Life cycle assessment - Requirements and guidelines, International Organization for Standardization.

Kaziolas D.N., Zygomalas I., Stavroulakis G. E., Emmanouloudis D., and Baniotopoulos C. C., 2013. Evolution of environmental sustainability for timber and steel construction. Smart Innovation, Systems and Technologies, vol. 22, pp. 25-33.

The Netherlands Ministry of Housing, Spatial Planning and the Environment, 2000. Eco-Indicator 99, Manual for designers: A damage oriented method for Life Cycle Impact Assessment.

Zygomalas I., Efthymiou E., Baniotopoulos C. and Blok R. 2012. A newly developed Life Cycle Inventory (LCI) database for commonly used structural steel components. Structure and Infrastructure Engineering, Taylor \& Francis Group. Volume 8, Issue 12, pp. 1173-1181.

Zygomalas I., Kaziolas D.N., Stavroulakis G.E. and Baniotopoulos C.C., 2013. Life Cycle Assessment of a Steel-Framed Residential Building. Proceedings of the Fourteenth International Conference on Civil, Structural and Environmental Engineering Computing, B.H.V. Topping and P. Iványi, (Editors), Civil-Comp Press, Stirlingshire, United Kingdom, paper 152, 2013. doi:10.4203/ccp.102.152 